\title{
Meandry polsko-czeskiej współpracy filmowej w dwudziestoleciu międzywojennym
}

Zastanawiając się nad polsko-czeską współpracą w obrębie kinematografii przed wybuchem II wojny światowej, najczęściej odwołujemy się do komedii Dwanaście krzeset (Dvanáct křesel, 1933, reż. Martin Frič, Michał Waszyński). Ów film zapisał się w historii nie tylko jako pierwsza polsko-czeska koprodukcja, lecz także jako obraz pojedynku aktorskiego Adolfa Dymszy i Vlasty Buriana. Czy jednak na tym jednym dziele zamyka się historia polsko-czeskich relacji filmowych w okresie międzywojnia? Filmoznawcy zazwyczaj pomijają to zagadnienie, koncentrując się na narodowym aspekcie młodych kinematografii.

Jednocześnie trudno jest zakładać szeroką polsko-czeską współpracę w okresie międzywojennym wiedząc, że droga do zbliżenia się krajów po odzyskaniu niepodległości była zawiła. Przypomnijmy, że spór graniczny powstały po niezrealizowanych planach Tomáša Garrigue’a Masaryka dotyczących stworzenia unii czechosłowacko-polskiej (1917), dotyczył ziem Śląska Cieszyńskiego i rozegrał się w kilku etapach. W rezultacie etnicznego podziału granic Czechosłowacja wypowiedziała Polsce siedmiodniową wojnę, która zakończyła się w 1920 roku nowym podziałem. Polska, osłabiona konfliktem zbrojnym z bolszewikami, uznała decyzję Rady Ambasadorów pod warunkiem przepuszczenia przez Czechosłowację alianckich transportów z bronią dla Wojska Polskiego. Jednak władze południowego sąsiada nie spełniły żądania. Podczas gdy Polacy aspirowali do przynajmniej częściowego przywrócenia obszaru przedrozbiorowej Rzeczpospolitej, rząd Republiki Czechosłowackiej (ČSR) popierał dążenia polityków rosyjskich z frakcji Białych do przyłączenia Galicji Wschodniej w obręb przyszłej demokratycznej i federalnej Rosji. Politycy czechosłowaccy zakładali, że granica ze wschodnią potęgą pomoże im w zdobyciu pozycji lidera Europy Srodkowo-Wschodniej i zapewni gwarancję integralności terytorialnej.

Poprawa relacji nastąpiła w związku z poparciem rządu w Pradze dla polskich postulatów na Górnym Śląsku w 1921 roku oraz z zawarciem

* Národní filmový archiv, Praga. 
umowy o mniejszościach narodowych (1925). Podsumowując stosunki dyplomatyczne między Warszawą i Pragą w latach 1918-1938, badacze wyróżniają następujące okresy: normalizacji (1920-1925), zbliżenia i rozbieżności (1925-1933) oraz antagonizmu (1933-1938)1. Jak zobaczymy dalej, ów podział ma także przełożenie na filmową kooperację sąsiadów.

Kluczowe pytanie, które warto w tym miejscu zadać, brzmi: jak kształtowała się czesko-polska granica filmowa w momencie pojawienia się na mapie Europy dwóch młodych państwowości?

Z uwagi na brak szczegółowych opracowań oraz dostępu do wielu źródeł niniejszy tekst nie może przynieść wyczerpującego przedstawienia tego zagadnienia. Chociaż artykuły prasowe i broszury, z których korzystam, zawierają cenne informacje, nie zawsze można zweryfikować ich wiarygodność. Niemniej spróbuję podsumować dotychczasową kwerendę polskiej i czeskiej literatury dotyczącej tego tematu. Zdaję sobie zarazem sprawę, że poruszone przeze mnie kwestie recepcji filmów oraz dystrybucji filmowej wymagają oddzielnych, bardziej szczegółowych badań.

Na podstawie materiałów z okresu dwudziestolecia międzywojennego można stwierdzić, że w latach normalizacji stosunków z ČSR (19201925) Polacy nie byli zainteresowani obecnością na jej rynku filmowym. Chociaż w Czechosłowacji do dystrybucji wchodziło średnio 500-600 filmów rocznie, przeważały produkcje z państw zachodnich, a filmy z krajów słowiańskich należały do mniejszości².

Niestety, niemożliwe było oszacowanie, ile dokładnie czeskich obrazów wyświetlono w polskich kinach w latach 1918-1938. Najwcześniejsze dostępne informacje na temat współpracy polsko-czeskiej datowane są na rok 1918 i pochodzą z materiałów archiwalnych Bohumila Vese-

${ }^{1}$ Zob. Janusz Gruchała, Czeskie środowiska polityczne wobec spraw polskich 1920-1938, Wydawnictwo Uniwersytetu Śląskiego, Katowice 2002. Używając przymiotnika „czeski” oraz „czechosłowacki”, kieruję się myślą Andrzeja Essena, zgodnie z którą: "Należy podkreślić, że próba przeglądu osiągnięć historiografii polskiej w badaniach nad dziejami Czech czy stosunków polsko-czeskich musi w sposób oczywisty dotyczyć odniesień polsko-czechosłowackich, jako że nie można wydzielić odniesień polsko-czeskich, jeśli badamy stosunki międzypaństwowe w latach 1918-1939 czy 1945-1992 na polu polityczno-dyplomatycznym czy gospodarczym. Jedynie odniesienia kulturalne czy społeczne można rozdzielić i badać oddzielnie związki polsko-czeskie czy polsko-słowackie". Zob. Andrzej Essen, Stosunki polsko-czeskie (czechosłowackie) w historiografii polskiej po 2000 roku, „Historia Slavorum Occidentis” 2011, nr 1, s. 187.

${ }^{2} \mathrm{~W}$ czechosłowackiej dystrybucji dominowały filmy ze Stanów Zjednoczonych (na przykład w 1925 roku zakupiono 350 amerykańskich filmów), Niemiec (w 1925 roku - 141 filmów) oraz Francji (w 1925 roku - 48 filmów), zob. Ivan Klimeš, Kinematografie a stát v českých zemích 1895-1945, Univerzita Karlova v Praze, 2016, s. 163. 
lego ${ }^{3}$. W dokumentacji dotyczącej znanego praskiego kina Lido Bio znajduje się nota, zgodnie z którą we lwowskiej filii wspomnianego biografu odbyły się pokazy czechosłowackiego filmu Ahasver (reż. Jaroslav Kvapil, 1915, Austro-Węgry) z polsko-niemieckimi napisami. Kino to miało zarazem funkcjonować jako firma produkująca czeskie filmy $y^{4}$. Jednak $\mathrm{w}$ polskiej prasie ze wspominanego okresu wzmianki na temat projekcji obrazów znad Wełtawy pojawiają się rzadko. Dzięki praskim ulotkom reklamowym wiadomo, że na początku lat 20. Polacy zakupili dwa filmy: Nad propastí (Nad przepaścia, reż. Vladimír Majer, 1922) oraz Závět’ podivínova (Testament dziwaka, reż. Zet Molas, 1924). Pierwszy z nich przedstawia dramatyczną opowieść o bezwzględnej kobiecie, która pragnie zniszczyć mężczyznę, drugi to romantyczna historia miłosna, zrealizowana w scenerii starego pałacu ${ }^{5}$.

Należy jednak miećświadomość, że czeska kinematografia dopiero poszukiwała swojego miejsca na mapie filmowej Europy. W latach 20. filmy sąsiadów nie odznaczały się wysokim poziomem, a twórcy w mniej lub bardziej udany sposób kopiowali schematy kina amerykańskiego.

Co więcej, kiedy w 1924 roku przez czeskie gazety przetoczyła się debata dotycząca małej siły przebicia rodzimych filmów za granicą, podkreślano różnicę w stabilności waluty między Czechosłowacją a innymi krajami:

[...] Państwa z walutą niższą niż nasza, czyli Niemcy, Austria, Węgry, Polska i Jugosławia, nie wchodzą w grę, ponieważ nie są w stanie zapłacić za monopol nawet stosunkowo niskiej kwoty. Jeżeli w ogóle jakieś nasze filmy trafily na zagraniczny rynek, nie był to efekt sprzedaży, ale kompensacji, zdobytej po wielu negocjacjach, podróżach i kompromisach. Na chwilę obecną oraz w najbliższej przyszłości nasz film będzie ograniczony w eksploatacji jedynie na terytorium republiki. Słowacja nie jest satysfakcjonującym partnerem handlowym dla Czech i Moraw $[\ldots]^{6}$.

Szanse czeskich filmowców, aby podbić Polskę, były znikome. Od momentu odzyskania niepodległości do ostatecznego ustalenia granic z Czechosłowacją w kraju panowała hiperinflacja związana z nadmiernym deficytem budżetowym, który był skutkiem wojny polsko-bolszewickiej

${ }^{3}$ Bohumil Veselý (1903-1971) - jeden z pierwszych kolekcjonerów filmowych w przedwojennej Czechosłowacji, pasjonat filmu. Uwiecznił na taśmie filmowej szereg znanych osób ze świata filmu, sztuki i nauki.

${ }_{4}^{4}$ Zob. Národní filmový archiv, Bohumil Veselý: Písmenosti kina Lido Bio 1916-1936, [w:] Bohumil Veselý. Inventární seznam.

${ }^{5}$ Film Závět podivínova nie zachował się.

"Zob. b.a., Krise filmové domácí výroby, „Filmové zprávy” 1923, nr 1, s. 4. 
oraz zamachu na prezydenta Narutowicza. W okresie największego kryzysu ekonomicznego (w latach 1923-1926) liczba kin drastycznie spadła z 850 w 1922 roku do 424 w roku 19247. Główną siłę przebicia posiadały zagraniczne koncerny, odpowiedzialne nie tylko za głośne tytuły, lecz także za całe zaplecze techniczne, którego nie było w Polsce. Z powodu zaistniałej sytuacji rynek krajowy został szybko zdominowany przez import, głównie filmów amerykańskich.

Na brak współpracy między Warszawą i Pragą w obrębie kinematografii z pewnością wpłynęły również kwestie polityczne. Jakkolwiek „[...] rok 1920 kończy burzliwy okres «budowania państw» oraz wytyczania ich granic" ${ }^{\prime \prime}, \mathrm{w}$ obu krajach nadal pojawiały się silne wyrazy nieufności wobec sąsiada.

Według badaczy wpływ na częściową zmianę w relacjach miał dopiero przewrót majowy. Sławomir M. Nowinowski pisze:

Szczęśliwie dla Polski, przewrót majowy nie osłabił przymierza z Rumunią [...]. Obiecująco rysowała się także perspektywa warszawskiego poselstwa w ČSR wobec przyszłości stosunków polsko-czechosłowackich. Zaleski, wdzięczny za poparcie przez Beneša polskich starań o członkostwo w Radzie Ligi Narodów, nazwał go przyjacielem, na którego pomoc można zawsze liczyć. Nawet Piłsudski, znany aż nadto z niechętnego nastawienia do I Republiki, zdobył się na kilka gestów sympatii pod jej adresem. U schyłku 1926 roku Flieder był pewien, że rząd polski, chcąc uniknąć osamotnienia w Europie, będzie zmuszony dojść z Pragą do porozumienia9

Pozytywne komentarze wobec ościennego kraju, które zaczęły pojawiać się w prasie obu państw, stanowiły efekt zawarcia czechosłowacko-polskiej umowy prasowej w 1928 roku $^{10}$. Dziennikarze wyjeżdżali służbowo w celu zapoznania się z kulturą i warunkami życia drugiego państwa ${ }^{11}$. Na początku lat 30. przy placówkach dyplomatycznych ČSR

7 Dla porównania, w Czechosłowacji w 1922 roku działało wówczas 712 kin. Zob. Ivan Klimeš, Kinematografie a stát v českých zemích..., s. 150.

8 Jaroslav Valenta, Masaryk i sprawy polskie, "Dzieje Najnowsze” 1932, nr 3, s. 76.

9 Sławomir M. Nowinowski, Ministerium Augusta Zaleskiego (1926-1932) w ocenie dyplomacji ČSR, „Dzieje Najnowsze” 1936, nr 2, s. 55. Robert Flieder, poseł i dyplomata ČSR, pełniący funkcję ambasadora w Warszawie w latach 1924-1927.

10 Zob. Andrzej Essen, Stosunki polsko-czeskie..., s. 54: „O tym, że dziennikarze kształtowali opinię publiczna, świadczą słowa J. V. Šmejkala na łamach «Českého slova»: Nie wierzę, żeby kiedyś nasz lud czuł nienawiść do ludu polskiego, lud polski do czechosłowackiego. Wykluczone! Były to tylko źle nastrojone narzędzia obu dyplomacji i niedobrze pisane noty prasy".

11 Tamże; Grażyna Pańko, Polska i Polacy w czeskiej opinii publicznej w okresie międzywojennym, „Acta Universitatis Wratislaviensis" 1996, nr 1829, Historia CXXVII. 
działały instytuty propagujące sąsiednią kulturę. Co ciekawe, Czechosłowacja miała w Polsce konsulaty w Krakowie (1919-1939), Katowicach (1924-1937), Poznaniu (1921-1936), Lwowie (1921-1939), Gdyni (19371939), Urząd Paszportowy w Cieszynie (1920-1924) oraz Konsulat Honorowy w Kwasiłowie (1931-1939).

Wróćmy do kwestii filmowej. Przeglądając prasę, można zauważyć, że od końca lat 20. temat polskiej kinematografii regularnie pojawia się w czeskiej prasie filmowej, a czeskiej - w polskiej. W 1928 roku „Filmový kurýr" informuje, iż nad Wisłą zostało powołane Biuro Przemysłu Filmowego, które wydało ustawę dotyczącą opodatkowania krajowych i zagranicznych filmów ${ }^{12}$. Ponadto niniejszy numer pisma zawiera zapowiedź projekcji filmu Huragan (reż. Józef Lejtes, 1928) w Pradze, która odbędzie się dzięki wsparciu ze strony polskiego konsulatu oraz pracy Polaków nad adaptacją Przedwiośnia (reż. Henryk Szaro, 1928). W polskim „Informatorze Filmowo-Teatralnym" można tymczasem przeczytać recenzję filmu Erotikon (reż. Gustav Machatý, 1929), z której dowiadujemy się, że:

Przez całe lata produkcja czeska przeżywała ciężki kryzys i chociaż nie ustawała
w pracy, to jednak nie mogła wybić się ponad przeciętność i szablon ${ }^{13}$. Autorka tekstu
pokłada nadzieję w twórczości Machatego: „Reżyser udowodnił, że ma w sobie zada-
tek na realizatora najwyższej klasy i że zacząwszy w młodym stosunkowo wieku, ma
przed sobą przyszłość wielką i pewną. [...] Dajcie mu możność pracy w odpowied-
nich warunkach, a produkcja czeska stanie wkrótce w szeregu tych, z którymi się liczą
na rynkach międzynarodowych” ${ }^{14}$.

Erotikon to pierwszy film znad Wełtawy, który zdobył rozgłos w Polsce. Krytycy chwalili nie tylko kunszt reżysera, lecz docenili także talent młodej aktorki Ity Riny, wróżąc jej międzynarodowy sukces. W recenzjach powtarzają się uwagi na temat osiagnięć filmowych małego państwa, które nareszcie wyszło z cienia ${ }^{15}$.

Na przełomie lat 20. i 30. czeska kinematografia wyraźnie stanęła na nogi. Podczas gdy nad Wełtawą w 1929 roku powstało 35 obrazów, Polacy mogli pochwalić się zaledwie 15 produkcjami. O dynamicznie rozwijającym się przemyśle filmowym Czechów świadczy fakt, że tuż po wprowadzeniu dźwięku w filmie znany przedsiębiorca i producent Miloš Havel otrzymał pożyczkę od państwa na budowę nowego studia

12 Zob. b.a., Co se děje, „Filmový kurýr” 1928, nr 42, s. 7.

13 Zob. Nina Novilla, Erotikon. Wytwórczość filmowa w Czechach, „Informator Filmowo-Teatralny" 1929, nr 14-15, s. 2.

14 Tamże.

15 Zob. Recenzje filmowe. Eroticon, „KinoTeatr” 1929, nr 19, s. 11. 
na Barrandowie. Całkowity koszt projektu wyniósł czternaście milionów koron czechosłowackich. Polska strona uważnie przyglądała się funkcjonowaniu kinematografii czeskiej. W 1931 roku Karol Ripa, pełniący urząd konsula Polski w Ostrawie, wysłał pytanie do Ministerstwa Spraw Zagranicznych ČSR, dotyczące statusu prawnego działalności czechosłowackich przedsiębiorstw filmowych oraz systemu pokazów filmowych nad Wełtawa ${ }^{16}$. Natomiast w korespondencji między Ministerstwem Handlu i MSZ ČSR znajduje się nota pochodząca z 1933 roku, zgodnie z którą Polska, wzorując się na Czechosłowacji, zamierzała wprowadzić umowę kontyngentową ${ }^{17}$.

Przypomnijmy, że początek lat 30. to gorący okres w historii kina. W tym samym czasie obserwujemy zmiany związane z rewolucją dźwiękowa planem powstrzymania w Europie ekspansji produkcji amerykańskich i niemieckich oraz animozje na tle narodowym.

Zarówno Czesi, jak Polacy dostrzegli w tej sytuacji szansę do nawiązania współpracy. Ponadto nie bez znaczenia jest fakt, że oba kraje protestowały przeciw pokazom filmów w języku niemieckim. Luboš Bartošek pisze: „W dniach 22 i 27 września 1930 roku odbyły się w Pradze masowe demonstracje przeciwko niemieckim filmom. [...] Inicjatorzy reagowali na przytłaczające zwycięstwo nazistów w Niemczech oraz przejawy nasilającej się ekspansji faszystów, która była wymierzona w słowiańskie narodowości we Włoszech oraz Austrii"18. Potwierdzenie wypowiedzi czeskiego historyka możemy znaleźć w artykule przedwojennego „Kina”, gdzie Władysław Mergel, polski attaché w Czechosłowacji, konstatuje: „C.K. Marszałek Polny powinien być wyświetlany w Warszawie $\mathrm{w}$ wersji czeskiej. Byłaby to próba praktyczności propozycji, którą po antyniemieckich demonstracjach w Pradze rzuciłem pod adresem polskich producentów filmowych: Precz z filmami niemieckimi, niech żyją filmy słowiańskie!"19.

W 1932 roku w naszych kinach można było obejrzeć sześć obrazów z Czechosłowacji, w tym wspomnianą już koprodukcję Dwanaście krzeset.

\footnotetext{
${ }^{16}$ Zob. Archiwum MSZ ČR, Sekcja III 1918-1939, Zespół: Film: Podpora filmového průmyslu v Československu, nr 83.154, 1932.6.

17 Zob. Archiwum MSZ ČR, Sekcja III 1918-1939, Zespół: Dovoz amerických filmů, nr 129618/33. System kontyngentowy działał w Czechosłowacji w latach 1932-1934.

18 Zob. Luboš Bartošek, Náš film, Mladá fronta, Praha 1985, s. 171.

19 Władysław Mergel, Rzym i Praga daja znać o sobie. Renesans filmów włoskich - sukces filmu czeskiego, „Kino” 1930, nr 37, s. 5. Szerzej na temat bojkotu filmów niemieckojęzycznych w Polsce: Urszula Biel, Polsko-niemiecka wymiana filmowa w latach 1933-1939, [w:] Polska i Niemcy. Filmowe granice i sasiedztwa, red. Konrad Klejsa, Schamma Schahadat, Oficyna Wydawnicza Atut, Wrocław 2012, s. 34-36.
} 
Dwa lata później import widowisk wzrósł do dziesięciu i dorównał liczbie filmów zakupionych z Niemiec ${ }^{20}$.

Publicyści „Kina” poświęcili stosunkowo dużo uwagi Annie Ondrákovej oraz Vlascie Burianowi, porównując ich kunszt aktorski w obrazie On i jego siostra (On a jeho sestra, reż. Karel Lamač, 1931) z umiejętnościami gwiazd światowego kina. Równocześnie zarzucali rodzimym twórcom, że nie potrafią pracować z aktorami jak sąsiedni koledzy po fachu, którzy obsypują Polskę i Europę nowymi przebojami ${ }^{21}$. W artykułach poświęconych Ondrákovej podziwiano temperament i „wdzięczną urodę" aktorki oraz jej wrodzony dar zdobywania sympatii widza. Recenzje z czasopisma „Kino” zawierają także wyrazy uznania dla Karla Lamača. Zgodnie z opinią polskich krytyków reżyser „nieźle naśladuje wzory amerykańskie" i realizuje filmy „,z dużym poczuciem kinowym bez trywialnych akcentów, rażących zwłaszcza w komediach niemieckiego typu" ${ }^{\prime 22}$. Zasadnicza kwestia w ocenie dokonań Vlasty Buriana dotyczyła świadomej gry aktora, połączonej z naturalnym komizmem maski, który przewyższał sposób wyrazu Adolfa Dymszy ${ }^{23}$. Komedia On i jego siostra ujęła Polaków także dzięki czeskim dialogom, które: „[...] tak bliskie nam, bo zrozumiałe, wywołują wśród publiczności tem serdeczniejsze wybuchy śmiechu $^{\prime 24}$. Warto wspomnieć, że w Czechosłowacji pokazywano polskie filmy również w wersji oryginalnej. Na plakacie reklamującym Pałac na kótkach (reż. Ryszard Ordyński, 1932) widnieje komunikat, iż obraz posiada mało dialogów, więc będzie zrozumiały dla publiczności.

Czesi, chcąc zachęcić publiczność do polskiej kinematografii, zwracali uwagę na naszych aktorów. Artystą budzącym szczególne zainteresowanie sąsiadów okazał się Eugeniusz Bodo, którego nad Wełtawą uznano za najlepszego polskiego aktora. Jednak więcej miejsca poświęcano relacjom dotyczącym całokształtu dokonań niż omawianiu poszczególnych produkcji. W podsumowaniu filmowego dorobku Polaków, które zostało opublikowane w dzienniku „Lidové noviny” w 1934 roku, czytamy, że jakkolwiek przemysł filmowy nad Wisłą rozwija się w dobrym kierunku, twórcy nie wykorzystują w pełni możliwości oraz potencjału swojego kraju i zanadto koncentrują się na "romansach w parku”:

${ }^{20}$ W 1934 roku cenzura polska nie dotrzymała umowy z Niemcami, wpuszczając na ekrany zaledwie dziesięć niemieckich filmów. Zob. Urszula Biel, Polsko-niemiecka wymiana filmowa..., s. 42-43.

${ }^{21}$ Zob. b.a., Z ekranu na ekran, „Kino” 1931, nr 20, s. 14; b.a., Nasza okładka: Anny Ondra, „Kino" 1930, nr 13, s. 2.

${ }_{22}$ Zob. b.a., Z ekranu na ekran, „Kino” 1931, nr 20.

${ }_{23}$ Zob. tamże.

${ }^{24}$ b.a., Na ekranach stolicy, „Kino” 1931, nr 20, s. 10. 
Polscy scenarzyści i reżyserzy boją się problematyki społecznej jak ognia. Nie ma także szczęścia przemysłowa Łódź. Ziemia obiecana, która stanowi jedyny jak dotąd przykład na wykorzystanie plenerów miasta, z technicznego punktu widzenia nie wygląda źle, lecz jej temat został słabo opracowany. Czego by dokonali zagraniczni przedsiębiorcy, mając do dyspozycji magistralę Gdynia-Sląsk! Polacy nie podejmują w tym kierunku żadnych kroków ${ }^{25}$.

W maju 1933 roku powstał w Warszawie plan założenia biura Praga Film Sp. z o.o. z wyłącznym prawem eksploatacji obrazów wyprodukowanych przez czeskie firmy: A.B. - Film Sp. Akc., Elekta Film Sp. Akc., Slavia - Film oraz Moldavia - Film² ${ }^{26}$. Sposób organizacji kinematografii ościennego państwa cieszył się wówczas w Polsce dobrą opinia, o czym świadczy fakt, że porównywano go w krajowej prasie do modelu amerykańskiego ${ }^{27}$. Z kolei nad Wełtawą pojawiły się komentarze zachęcające do zacieśnienia kooperacji z Polską. Autor tekstu zamieszczonego w periodyku „Český filmový zpravodaj" zwraca uwagę, że należy utrzymywać dobre stosunki ze słowiańskim sąsiadem, który posiada duży rynek zbytu, wyszedł do Czechów z propozycją współpracy filmowej i wysoko ceni czeską kinematografię ${ }^{28}$.

Czytając recenzję na temat komedii obyczajowej 10\% dla mnie (reż. Juliusz Gardan, 1933), opublikowaną w periodyku „Film”, dowiadujemy się, że czeski dystrybutor Lloydfilm ma przed sobą trudne zadanie: jak przekonać właścicieli kin o walorach polskiej kinematografii. Według publicysty, aby osiągnąć ów cel, warto powołać się na przyjazne relacje obu krajów. Po raz kolejny zostaje tutaj przytoczona argumentacja podobieństwa języków oraz spłacenia długu, który posiadają Czesi w związku z popularnością ich filmów w Polsce ${ }^{29}$.

W czasopiśmie „Film” wydrukowano również krótką wzmiankę o porozumieniu między dwoma państwami, na mocy którego w Łodzi zostało powołane do życia Polsko-Czeskie Towarzystwo Filmowe „Poczetofilm”, planujące kręcić polskie filmy w wersji czeskiej oraz dystrybuować czeskie produkcje ${ }^{30}$.

${ }^{25}$ Zob. Svatopluk Ježek, Polský film na nové cesty, „Lidové noviny” 1934, nr 459, s. 6.

26 Zob. b.a., Komunikat, „Kino dla Wszystkich” 1933, nr 36, s. 11.

27 Zob. b.a., Rozwój produkcji czesko-stowackiej, „Kino dla Wszystkich” 1933, nr 41, s. 6.

28 Zob. b.a., Filmový styk s Jugoslavií navázány, "Český filmový zpravodaj” 1932, nr 26, s. 1.

${ }^{29}$ Zob. b.a., Z naších puijčoven, „Film” 1933, nr 13, s. 10.

30 Zob. b.a., "Film” 1933, nr 13, s. 11. Pierwszym polskim filmem wyświetlanym w czeskiej wersji językowej była Halka (reż. Konstanty Meglicki, 1930), prezentowana w czeskich kinach w 1933 roku. Zob. b.a., Halka proním polským filmem v české versi, „Filmový kurýr" 1933, nr 20, s. 2. Tereza Frodlová, Vypưjčené hlasy. Počátky dabingu v českých zemích v letech 1933-1942. Magisterská diplomová práce, Ústav filmu a audiovizuální kultury, Masarykova univerzita, Brno 2013, s. 31-32. 
Bazując na dotychczasowej kwerendzie, można wywnioskować, że po premierze komedii Dwanaście krzeset filmowcy zastanawiali się nad nakręceniem kolejnych koprodukcji. Jedną z nich miał być obraz o tematyce narodowej pt. Dcera národa (Córka narodu), oparty na monografii Cyryla Merhouta, którego główny wątek traktował o nieszczęśliwej miłości córki Karla Havlička Borovskiego do polskiego porucznika z Galicji barona Battaqliony. Na realizację filmu zdecydował się Karel Lamač przy współpracy z Josefem Neubergiem i Juliusem Schmittem. Autorzy projektu przewidywali, że dzieło powstanie w czesko-polskiej wersji językowej, gdzie aktorzy polskiej narodowości będą mówić w swoim języku. Kolejny pomysł dotyczył projektu o tematyce lotniczej pt. Hrdinové vzduchu (Bohaterowie przestworzy) w reżyserii Václava Binovca ${ }^{31}$. Niestety, trudno jednoznacznie stwierdzić, na ile powyższe informacje zostały potwierdzone przez realizatorów, a na ile stanowiły efekt kampanii medialnej.

Jest natomiast pewne, że oprócz cykli artykułów, szeregu spotkań oraz audycji radiowych na temat sąsiedniej kinematografii, członkowie Stowarzyszenia START zorganizowali w 1934 roku w Warszawie retrospektywę czechosłowackiej awangardy filmowej, której gościem honorowym był Svatopluk Ježek ${ }^{32}$. Pokaz posiadał charakter zamknięty i miał miejsce $\mathrm{w}$ najnowocześniejszym na owe czasy kinie polskim Atlantic. W trakcie projekcji zaprezentowano takie dzieła, jak: Symfonia architektury (Na pražském hradě, reż. Alexander Hackenschmied, 1931), Burleska (reż. Jan Kučera, 1932), Burza nad Tatrami (Bouřre nad Tatrami, reż. Tomáš Trnka, 1932), Żyjacy w Pradze (Žijeme v Praze, reż. Otakar Vávra, 1934) oraz fragmenty poematu Ziemia śpiewa (Zem spieva, reż. Karel Plicka, 1933) ${ }^{33}$.

Jednak sojusz bratnich narodów nie trwał długo. Pomimo importu polskich filmów do Czechosłowacji w latach 1931-19344 oraz zabiegów rodzimej prasy i dyplomatów zachęcających odbiorców do zapoznania

31 Zob. b.a., Dcera národa jako česko-polský film, „Lidové noviny” 1933, nr 640, s. 14.

32 W 1931 roku rozgłośnia radiowa w Katowicach zaprosiła Svatopluka Ježka do poprowadzenia audycji na temat czechosłowackiej kinematografii, o rok później filmowiec zorganizował w klubie filmowym w Brnie spotkanie z polskim krytykiem filmowym Karolem Fordem, poświęcone kinu polskiemu. Zob. Svatopluk Ježek, Rozmlouva s Karolem Fordem, „Svět ve filmu a v obrazech" 1934, nr 8, s. 5-6.

33 Zob. b.a., Úspěch české avantgardy v Polsku, "Lidové noviny” 14.03.1934, nr 136, s. 12. Szczegóły nieudanego pokazu opisał Łukasz Biskupski, zob. Łukasz Biskupski, Okres schyłkowy "Startu”, „Pleograf. Kwartalnik Akademii Polskiego Filmu” 2017, nr 4, http:// akademiapolskiegofilmu.pl/pl/historia-polskiego-filmu/pleograf/nowy-kanon/10/w-druku-okres-schylkowy-startu/618 (dostęp: 3.04.2018).

${ }^{34} \mathrm{~W}$ niniejszym okresie na czeskim rynku pojawiło się 21 polskich filmów, w 1931 roku - 5 filmów, 1932 - 4, 1933 - 6, 1934 - 6. Ivan Klimeš, Kinematografie a stát v českých zemích..., s. 194. 
się z dziełami północnego sąsiada, polskie filmy nie zostały przyjęte nad Wełtawą z entuzjazmem.

Według komentatora dwutygodnika „Filmový kurýr”:

W ostatnim czasie mogliśmy obejrzeć kilka polskich filmów. Dlaczego? Wiadomo przecież, że programy kin świeca pustkami. Nagle wydobyliśmy z zapomnienia leżącą od długiego czasu w Pradze Zepsuta krew, kupiliśmy Halkę itp. Polskie filmy pojawiły się u nas z braku laku. I Polska o tym wie [...]. Czeski film jest na wyższym poziomie niż polski, ów fakt nie podlega dyskusji. Jasno wyraził na ten temat opinię w Ruchu Słowiańskim Bolesław Lewicki. [...] Polska prasa o tym pisze, ale czeska - o rodzimej polityce jest źle informowana albo wcale. Gdzie tkwi ziarno zła? ${ }^{35}$

Konsternację wyraził także konsul Marian Kossow. Dyplomata, podkreślając propagandową funkcję dziesiątej muzy, zwrócił uwagę, że w celu utrzymania dobrych stosunków politycznych Warszawa i Praga powinny zadbać o adekwatną współpracę na polu filmowym. W opinii Kossowa dotychczasowa dystrybucja polskich obrazów w Czechosłowacji była nieprzemyślana i mało profesjonalna. Kierując się prawem pieniądza, dystrybutorzy odrzucili filmy wartościowe na korzyść słabych, które wprowadzono na rynek za półdarmo. W konsekwencji niniejszych poczynań polskie kino zyskało nad Wełtawą złą renomę, budząc niechęć kiniarzy oraz szerokiej widowni ${ }^{36}$.

W październiku 1933 roku Polska podniosła cło na czeskie produkcje, zrównując je z opłatami przeznaczonymi dla pozostałych państw. Ustawa, dotycząca opodatkowania zagranicznych produkcji do 40-50\% (w stosunku do $5 \%$ na filmy polskie), miała uchronić kraj przed zalewem importowanych filmów i wesprzeć eksport rodzimych widowisk. Wiadomość o niniejszej deklaracji spotkała się w Pradze z dezaprobatą. „Filmový kurýr" w nawiązaniu do artykułu z „Lidových novin” konstatuje, że powód wzrostu podatku wiąże się z ekspansją czeskich filmów w Polsce, które pierwotnie miały jedynie zapełnić lukę po ograniczeniu dowozu niemieckich filmów. Zgodnie z opinią publicysty zachowanie strony polskiej kwestionuje zapewnienia o gestach przyjaźni w obrębie współpracy filmowej ${ }^{37}$.

35 b.a., Překážky česko-polské spolupráce, „Filmový kurýr” 1933, nr 25, s. 3.

36 Zob. b.a., Polský konsul o česko-polské spolupráci, „Filmový kurýr” 1933, nr 28, s. 2. Przykładem filmu, który był ceniony przez polską krytykę, a nie wszedł do czechosłowackiej dystrybucji, jest Legion ulicy (Legie ulice, reż. Aleksander Ford, 1932); zob. b.a., Překážky česko-polské spolupráce.

37 Zob. b.a, Polsko-česká filmová politika, „Filmový kurýr” 1933, nr 35, s. 2; b.a., Americký dumping v Polsku?, „Filmový kurýr" 1933, nr 52, s. 2. 
Od końca 1934 roku doniesienia na temat czeskiej kinematografii pojawiają się w polskiej prasie rzadziej niż na początku lat 30. Jakkolwiek dorobek sąsiadów nadal jest prezentowany w pozytywnym świetle ${ }^{38}$, brakuje recenzji z bieżących filmów. Nad owym stanem ubolewa czeski konsul w sprawozdaniu dla Ministerstwa Spraw Zagranicznych ČSR:

Z czeskich filmów prezentują już tylko te stare, na przykład Baby z Ondrakova, Revizora z Burianem oraz On i jego siostra - i to w peryferyjnych biografach. W porównaniu z wspaniałościami wiedeńskich i amerykańskich filmów, nasze obrazy sprawiają marne wrażenie [...]. Z powodu obecnie napiętej sytuacji bardziej wartościowe dzieła nie są eksportowane - chociaż konkurencja byłaby możliwa, ponieważ opozycyjna endecka prasa, która jest bardzo antysemicka, podkreśla żydowski charakter wszystkich wielkich zagranicznych firm i nie zamyka oczu przed żydowskimi producentami w kraju $[\ldots]^{39}$

W latach 1935-1936 południowi sąsiedzi nie wprowadzili do dystrybucji żadnego polskiego obrazu. Chociaż nad Wisłą można było obejrzeć Janosika (Jánošík, reż. Martin Frič, 1935), trudno jednoznacznie stwierdzić, kiedy dokładnie miała miejsce jego oficjalna premiera ${ }^{40}$.

Dobrze zapowiadająca się współpraca między Pragą i Warszawą urwała się niemal z dnia na dzień. Powodem tej sytuacji był nie tylko brak adekwatnego zainteresowania polskimi filmami w Czechosłowacji, lecz także podłoże polityczne. Po podpisaniu deklaracji polsko-niemieckiej o niestosowaniu przemocy (1934) stosunki z Czechosłowacją uległy pogorszeniu. W piętnastą rocznicę czeskiego ataku na Śląsk Cieszyński spór o Zaolzie znów stał się aktualny. Polskie Ministerstwo Spraw Zagranicznych rozpoczęło antyczeską kampanię propagandową, która odbywała się drogą dyplomacji i wywiadu ${ }^{41}$.

W aktach przechowywanych w archiwum czeskiego Ministerstwa Spraw Zagranicznych znajduje się teczka z 1935 roku dotycząca bojkotu czeskich filmów w polskich kinach. Według informacji zamieszczonych w niniejszej dokumentacji Związek Polskich Teatrów Świetlnych uchwalił,

\footnotetext{
38 Zob. b.a., Żywotność filmu czechosłowackiego, „Świat Filmu” 1937, nr 3, s. 10.

39 Zob. Archiwum MSZ ČR, Sekcja III 1918-1939, Zespół: Boykot československých filmů v Polsku, nr 84.882/35.

40 Zob. Karol Ford, Cztery pokazy, „Wiadomości Filmowe” 1936, nr 6, s. 2 - autor recenzji filmu podaje, że prywatny seans został zorganizowany przy współudziale Związku Dziennikarzy i Publicystów Filmowych i odbył się w łódzkim kinie Capitol. Wiktor Brumer, Umiejętna kompozycja filmu (,Janosik”), „Wiadomości Filmowe” 1937, nr 3, s. 2 - recenzent pisze, że „zaznajomił się" z Janosikiem, lecz nie podaje szczegółów pokazu.

${ }_{41}$ Piotr Kołakowski, Między Warszawa a Praga. Polsko-czechosłowackie stosunki wojskowo-polityczne 1918-1939, Wydawnictwo Bellona,Warszawa 2007, s. 374.
} 
że z uwagi na prześladowania polskich obywateli w Czechosłowacji należy wycofać z programu kin czeskie filmy. Kilka nowych produkcji, które przedostało się nad Wisłę, powinno zostać zatrzymanych przez cenzurę. Oczywiście Czesi rozważali, jakie podjąć kroki w zaistniałej sytuacji:

\begin{abstract}
Ministerstwo Spraw Wewnętrznych, ustosunkowując się do powyższej noty, informuje, że zezwolenie na pokaz filmów można cofnąć pod warunkiem, iż wydarzenie prowadzi do zakłócenia porządku społecznego, narusza morale społeczne lub ma charakter przestępstwa. Należy zarazem podkreślić, że ilość polskich filmów poddanych cenzurze wyraźnie spadła. W 1933 roku dopuszczono do rozpowszechniania siedem polskich filmów, w 1934 - sześć filmów pełnometrażowych oraz trzy krótkie metraże. Na obecną chwilę nie przedłożono do zatwierdzenia cenzury żadnej polskiej produkcji $^{42}$.
\end{abstract}

Jakkolwiek oba kraje nadal w ograniczonym zakresie informowały się na temat rozwoju kinematografii, nie podpisały umowy handlowej dotyczącej wymiany filmów ${ }^{43}$. Pokazy obrazów pochodzących z ościennego państwa odbywały się głównie dzięki aktywności konsulatów ${ }^{44}$.

Zmiany w sposobie dystrybucji, które Polska postanowiła wprowadzić, dążąc do stabilizacji własnego rynku, miały pierwotnie dotyczyć zawierania osobnych umów kontyngentowych ze wszystkimi krajami ${ }^{45}$. Aczkolwiek z prasy obu państw wynika, że Polacy, obserwując do czego doprowadziły kontyngentowe ustalenia w Czechosłowacji, wstrzymali się z podjęciem ostatecznej decyzji ${ }^{46}$.

Do momentu zajęcia przez wojska hitlerowskie Czech i Moraw w 1938 roku nic już się nie zmieniło między Warszawą i Pragą w kwestii współpracy filmowej. Kooperacja, którą podjęto po zakończeniu II wojny światowej, jest lepiej udokumentowana niż ta z dwudziestolecia między-

42 Zob. Archiwum MSZ ČR, Sekcja III 1918-1939, Zespół: Boykot československých filmů...

${ }^{43}$ Zob. Archiwum MSZ ČR, Sekcja III 1918-1939, nr 143603/III/36.

${ }_{44}$ Zob. Archiwum MSZ ČR, Sekcja III 1918-1939, Zespół: Večer filmů francouzské avantgardy ve Varšavě, nr 144/37. W korespondencji między czechosłowackim MSZ oraz Ambasadą Czechosłowacji w Warszawie można przeczytać o planach zorganizowania dwóch pokazów poświęconych czeskiej awangardzie filmowej i wydaniu czeskiego numeru „Filmu Artystycznego".

45 Zob. Urszula Biel, Polsko-niemiecka wymiana filmowa..., s. 43.

${ }^{46}$ Zob. Zniesienie kontyngentu filmowego w Czechostowacji, „Kino i Rewja dla Wszystkich" 1934, nr 13, s. 2; b.a., Americký dumping v Polsku, w którym można przeczytać, że: „Przed jakimś czasem Polskie Ministerstwo Handlu poprosiło nas o wyrażenie opinii w sprawie czechosłowackiego kontyngentu. Doradziliśmy wówczas przede wszystkim zawarcie umowy z Ameryka, żeby nie doszło do takiej sytuacji jak u nas, tylko w znacznie większym zakresie". 
wojennego. Podsumowując niniejsze rozważania, warto przypomnieć komentarz Ignacego Paderewskiego w sprawie ustalenia granic z Czechosłowacją: „Decyzja powzięta przez Konferencję Ambasadorów wykopała pomiędzy dwoma narodami przepaść, której nic wypełnić nie zdoła" ${ }^{47}$. Podjęta przez Polaków i Czechów na początku lat 30. próba wymiany filmowej stanowi krok w stronę wypełnienia owej „przepaści”.

\section{Bibliografia}

\section{Archiwalia}

Archiwum Ministerstwa Spraw Zagranicznych Republiki Czeskiej, Sekcja III 1918-1939, nr 143603/36.

Archiwum Ministerstwa Spraw Zagranicznych Republiki Czeskiej, Sekcja III 1918-1939, Zespół: Boykot československých filmů v Polsku, nr 84.882/35.

Archiwum Ministerstwa Spraw Zagranicznych Republiki Czeskiej, Sekcja III 1918-1939, Zespół: Dovoz amerických filmů, nr 129618/33.

Archiwum Ministerstwa Spraw Zagranicznych Republiki Czeskiej, Sekcja III 1918-1939, Zespół: Film: Podpora filmového průmyslu v Československu, nr 83.154/1932.6.

Archiwum MSZ ČR, Sekcja III 1918-1939, Zespół: Večer filmů francouzské avantgardy ve Varšavě, nr 144/37.

Národní filmový archiv, Bohumil Veselý: Písmenosti kina Lido Bio 1916-1936, [w:] Bohumil Veselý. Inventární seznam.

\section{Druki zwarte}

Bartošek Lubos, Náš film, Mladá fronta, Praha 1985.

Biel Urszula, Polsko-niemiecka wymiana filmowa w latach 1933-1939, [w:] Polska i Niemcy. Filmowe granice i sasiedztwa, red. Konrad Klejsa, Schamma Schahadat, Oficyna Wydawnicza Atut, Wrocław 2012.

Frodlová Tereza, Vypưjčené hlasy. Počátky dabingu v českých zemích v letech 1933-1942. Magisterská diplomová práce, Ústav filmu a audiovizuální kultury, Masarykova univerzita, Brno 2013.

Gruchała Janusz, Czeskie środowiska polityczne wobec spraw polskich 1920-1938, Wydawnictwo Uniwersytetu Śląskiego, Katowice 2002.

Klimeš Ivan, Kinematografie a stát v českých zemích 1895-1945, Univerzita Karlova v Praze, Praha 2016.

Kołakowski Piotr, Między Warszawa a Praga. Polsko-czechosłowackie stosunki wojskowo-polityczne 1918-1939, Wydawnictwo Bellona, Warszawa 2007.

47 Zob. http://www.archiwum.kc-cieszyn.pl/zaolzie1938/zaolzie/cytaty.htm (dostęp: 31.10.2017). 
Iwona Łyko

\section{Czasopisma}

b.a., Americký dumping v Polsku?, „Filmový kurýr" 1933, nr 52.

b.a., Co se děje, „Filmový kurýr" 1928, nr 42.

b.a., Dcera národa jako česko-polský film, „Lidové noviny” 1933, nr 640.

b.a., Filmový styk s Jugoslavií navázány, "Český filmový zpravodaj” 1932, nr 26.

b.a., Halka proním polským filmem v české versi, „Filmový kurýr” 1933, nr 20.

b.a., Komunikat, „Kino dla Wszystkich” 1933, nr 36.

b.a., Krise filmové domácí výroby, „Filmové zprávy” 1923, nr 1.

b.a., Na ekranach stolicy, „Kino” 1931, nr 20.

b.a., Nasza okładka: Anny Ondra, „Kino” 1930, nr 13.

b.a., Polsko-česká filmová politika, „Filmový kurýr" 1933, nr 35.

b.a., Polský konsul o česko-polské spolupráci, „Filmový kurýr" 1933, nr 28.

b.a., Překážky česko-polské spolupráce, „Filmový kurýr” 1933, nr 25.

b.a., Rozwój produkcji czesko-słowackiej, „Kino dla Wszystkich” 1933, nr 41.

b.a., Úspěch české avantgardy v Polsku, „Lidové noviny” 14.03.1934, nr 136.

b.a., Z ekranu na ekran, "Kino” 1931, nr 20.

b.a., Z naších pưjčoven, "Film” 1933, nr 13.

b.a., Żywotność filmu czechosłowackiego, „Świat Filmu” 1937, nr 3.

Biskupski Łukasz, Okres schyłkowy "Startu”, „Pleograf. Kwartalnik Akademii Polskiego Filmu" 2017, nr 4, http://akademiapolskiegofilmu.pl/pl/historia-polskiego-filmu/pleograf/nowy-kanon/10/w-druku-okres-schylkowy-startu/618 (dostęp: 3.04.2018).

Brumer Wiktor, Umiejętna kompozycja filmu ( "Janosik”), „Wiadomości Filmowe” 1937, nr 3.

Essen Andrzej, Stosunki polsko-czeskie (czechosłowackie) w historiografii polskiej po 2000 roku, „Historia Slavorum Occidentis” 2011, nr 1.

Ford Karol, Cztery pokazy, „Wiadomości Filmowe” 1936, nr 6.

Ježek Svatopluk, Polský filmový svět, „Lidové noviny” 1934, nr 165.

Ježek Svatopluk, Polský film na nové cesty, „Lidové noviny” 1936, nr 459.

Ježek Svatopluk, Rozmlouva s Karolem Fordem, "Svět ve filmu a v obrazech" 1934, nr 8.

Mergel Władysław, Rzym i Praga daja znać o sobie. Renesans filmów włoskich - sukces filmu czeskiego, „Kino” 1930, nr 37.

Novilla Nina, Erotikon. Wytwórczość filmowa w Czechach, "Informator Filmowo-Teatralny” 1929, nr 14-15.

Nowinowski Sławomir M., Ministerium Augusta Zaleskiego (1926-1932) w ocenie dyplomacji ČSR, „Dzieje Najnowsze” 1936, nr 2.

Pańko Grażyna, Polska i Polacy w czeskiej opinii publicznej w okresie międzywojennym, „Acta Universitatis Wratislaviensis" 1996, nr 1829, Historia CXXVII.

Recenzje filmowe. Eroticon, „KinoTeatr” 1929, nr 19.

Valenta Jaroslav, Masaryk i sprawy polskie, „Dzieje Najnowsze” 1932, nr 3.

Zniesienie kontyngentu filmowego w Czechosłowacji, „Kino i Rewja dla Wszystkich” 1934, nr 13.

\section{Źródła internetowe}

http://www.archiwum.kc-cieszyn.pl/zaolzie1938/zaolzie/cytaty.htm (dostęp: 31.10.2017).

Zaolzie 1938. Dokumenty - relacje - opinie, http://zaolzie.kccieszyn.pl/index.php/content,654/ (dostęp: 31.10.2017). 
Meandry polsko-czeskiej współpracy filmowej...

\section{Streszczenie}

Przedmiotem artykułu są polsko-czeskie relacje w obrębie kinematografii w wymiarze historycznym. Na podstawie materiałów źródłowych (prasy filmowej i dokumentów archiwalnych) odtworzona zostaje instytucjonalna mapa polsko-czeskich spotkań filmowych przed II wojną światową. W tekście zostały poruszone zagadnienia recepcji filmowej, dystrybucji oraz polsko-czeskich projektów filmowych. Badaczka, kreśląc ramy współpracy sąsiednich krajów, rozpoznaje okresy ich zbliżenia (1928-1934) oraz rozbieżności (1935-1938). Artykuł, będąc próbą konceptualizacji tematu, stanowi przyczynek do kolejnych, bardziej szczegółowych badań. 